\title{
Pengaruh Profitabilitas Dan Kompleksitas Operasi Pada Audit Delay Dengan Ukuran Perusahaan Sebagai Variabel Moderasi
}

\author{
Adhika Candra Putra ${ }^{1}$ \\ I Dewa Nyoman Wiratmaja ${ }^{2}$ \\ ${ }^{1,2}$ Fakultas Ekonomi dan Bisnis Universitas Udayana (Unud), Bali, Indonesia \\ e-mail: adhika.candraputra@gmail.com
}

\begin{abstract}
ABSTRAK
Penelitian ini bertujuan untuk menguji pengaruh profitabilitas dan kompleksitas operasi pada audit delay dan menguji pengaruh ukuran perusahaan sebagai variabel pemoderasi. Penelitian ini dilakukan pada perusahaan pertambangan yang terdaftar di Bursa Efek Indonesia Tahun 2013-2017 yang diakses melalui www.idx.co.id. Purposive sampling digunakan sebagai metode dalam pengambilan sampel dengan jumlah sampel sebanyak 50. Teknik analisis yang digunakan dalam penelitian ini adalah Regresi Linear Berganda untuk menguji pengaruh langsung profitabilitas dan kompleksitas operasi pada audit delay dan Moderated Regression Analysis untuk menguji ukuran perusahaan sebagai pemoderasi pengaruh profitabilitas dan kompleksitas operasi pada audit delay. Hasil penelitian menunjukan profitabilitas berpengaruh negatif pada audit delay. Kompleksitas operasi tidak berpengaruh pada audit delay. Ukuran perusahaan meperkuat pengaruh negatif profitabilitas pada audit delay. Ukuran perusahaan tidak mampu memoderasi pengaruh kompleksitas operasi pada audit delay.
\end{abstract}

Kata Kunci: Profitabilitas, kompleksitas operasi, ukuran perusahaan, audit delay

\begin{abstract}
This study aims to examine the effect of profitability and operational complexity on audit delay and test the effect of size of the company as moderating variable. This research was conducted at mining companies listed on Indonesia Stock Exchange in 2013-2017 which were accessed through www.idx.co.id. The sampling method used was purposive sampling with a total sample of 50. The analysis technique used in this study was Multiple Linear Regression to examine the direct effect of profitability and operational complexity on audit delay and Moderated Regression Analysis to test firm size as moderating influence profitability and operational complexity in audit delay. The results showed that profitability had negative effect on audit delay. The operational complexity has no effect on audit delay. The size of the company strengthens the negative effect of audit delay on profitability. Firm size is not able to moderate the influence of operational complexity on audit delay.
\end{abstract}

Keywords: Profitability, complexity of company operation, firm size, audit delay

\section{PENDAHULUAN}

Keputusan investor dalam berinvestasi pada Bursa Efek Indonesia (BEI) dipengaruhi oleh berbagai faktor. Salah satu faktor tesebut adalah laporan keuangan perusahaan emiten, yaitu dengan mengamati laporan keuangan emitendi 
Bursa Efek Indonesia. Laporan keuangan ini akan tepat guna bagi penggunanya apabila memiliki karakteristik kualitas agar informasi laporan keuangan bermanfaat bagi penggunanya. Karakteristik tersebut adalah bisa dipahami, andal, relevan, dan dapat diperbandingkan. Relevansi dari laporan keuangan dapat tercermin dari ketepatan waktu penyajian laporan keuangan tersebut.

Perusahaan publik yang terdaftar di Bursa Efek Indonesia (BEI) diwajibkan patuh dalam menyampaikan laporan keuangan yang telah diaudit secara berkala sebagai bentuk tanggung jawab manajemen kepada investor. Perusahaan diwajibkan untuk menyampaikan laporan keuangan tahunan kepada Otoritas Jasa Keuangan (OJK) paling lambat bulan keempat setelah tahun buku berakhir, hal ini tertuang dalam Peraturan (OJK) No. 29/POJK.04/2016 pada Pasal 7 ayat 1. Perusahaan yang terlambat dalam penyampaian laporan keuangannya akan dikenakan sanksi,yaitu: peringatan tertulis, denda, pembatasan kegiatan usaha, pembekuan kegiatan usaha, pencabutan izin usaha, pembatalan persetujuan dan pembatalan pendaftaran.

Pada Bursa Efek Indonesia (BEI), laporan keuangan yang telah diaudit mungkin menjadi satu-satunya sumber informasi terpercaya dibandingkan dengan informasi lainnya di Bursa Efek Indonesia (BEI). Dikutip dari publikasi Bursa Efek Indonesia (BEI) terdapat 18 perusahaan terbuka atau emiten yang belum menyampaikan laporan keuangan auditan tahun 2015, dimana perusahaan publik yang belum menyampaikan laporan auditan sebagian besar perusahaan pertambangan. Pada tahun 2017, mengutip dari CNN Indonesia, Bursa Efek Indonesia mengganjar denda dan menghentikan sementara (suspensi) perdagangan 
saham 17 perusahaan tercatat (emiten) karena belum menyampaikan laporan keuangan auditan periode 31 Desember 2016, salah satu perusahaan yang tidak tepat waktudalammenyampaikan laporan keuangan auditan adalah PT Borneo Lumbung Energi dan Metal Tbk serta Berau Coal Energy Tbk. Tahun 2018 dikutip dari publikasi Bursa Efek Indonesia (BEI) disebutkan bahwa terdapat 10 perusahaan terdaftar (emiten) yang terlambat menyampaikan lapora auditan periode 31 Desember 2017, diantaranya PT Bara Jaya Internasional Tbk, PT Borneo Lumbung Energi dan Metal Tbk, dan PT Cakra Mineral Tbk dimana perusahaan tersebut juga terlambat penyampaian laporan auditannya pada tahun sebelumnya.

Bagi perusahaan go public penyampaian laporan keuangan yang terlambat menyebabkan informasi yang terkandung dalam laporan keuangan kehilangan relevansi dan respon yang tidak baik dari pelaku pasar modal. Ketepatan waktu dalam publikasi laporan keuangan dapat mempengaruhi nilai perusahaan, karena terdapat informasi penting didalamnya.

Teori yang tepat untuk menjelaskan fenomena tersebut adalah teori agensi dan teori signal. Teori agensi dalam hal ini menjelaskan adanya biaya agensi yang dikeluarkan untuk memonitoring perilaku agen sehingga waktu pelaporan laporan keuangan auditan yang lambat akan dapat diatasi (Jensen, M. C., 1976). Penyampaian laporan audit yang terlambat juga dapat membuat pelaku pasar modalberkurang kepercayaannya pada laporan yang disajikan (Ilaboya \& Christian, 2014). Teori signal menjelaskan bahwa apabila didalam laporan keuangan perusahaan mengandung informasi yang merupakan berita baik bagi 
investor, maka perusahaan cenderung akan mempercepat publikasi laporan keuangan, sebaliknya apabila dalam laporan keuangan perusahaan mengandung berita buruk bagi investor maka perusahaan akan cenderung menahan publikasi laporan keuangan perusahaannya.

Faktor yang akan diuji adalah profitabilitas. Profitabilitas menunjukkan kemampuan perusahaan dalam memperoleh keuntungan, penilaian tingkat profitabilitas suatu perusahaan ditunjukkan dari laba bersih (Haryani dan Wiratmaja, 2014). Profitabilitas dapat menjadi faktor terjadinya audit delay. Tingkat profitabilitas yang rendah cenderung menyebabkan perusahaan menunda penyampaian laporan keuangan auditan sehingga audit delay terjadi semakin lama. Hal ini disebabkan tingkat profitabilitas yang rendah merupakan badnews bagi investor. Wulan dan Wiratmaja (2017) dan Prabasari dan Lely (2017) menyatakan bahwa profitabilitas berpengaruh negatif pada audit delay. Sebaliknya, Mega dan Budhiarta (2018) menyatakan bahwa profitabilitas berpengaruh positif pada audit delay.

Kompleksitas operasi adalah akibat dari adanya departemen dan pembagian pekerjaan yang memiliki fokus terhadap jumlah unit yang berbeda. (Yoga dan Sari, 2017). Silvia dan Wirakusuma (2013) menyatakan bahwa kompleksitas operasi perusahaan berpengaruh terhadap audit delay, sedangkan hasil penelitian Dian dan Yeni (2014) menemukan bahwa kompleksitas operasi perusahaan tidak berpengaruh terhadap audit delay.

Profitabilitas, kompleksitas operasi, dan ukuran perusahaan dipilih sebagai faktor yang akan diuji dikarenakan faktor-faktor tersebut faktor-faktor internal 
perusahaan yang mungkin menjadi penyebab audit delay yang terjadi. Pengujian ukuran sebagai faktor yang mempengaruhi audit delay dilakukan oleh Dyer dan McHugh (1975), Carslaw dan Kaplan (1991), dan Owusu dan Ansah (2000).

Ukuran perusahaan dipilih sebagai variabel moderasi karena secara teoritis apabila perusahaan dengan aktiva yang besar, maka perusahaan tersebut akan mengungkapkan informasi yang lebih banyak dibandingkan dengan perusahaan berukuran kecil. Perusahaan dengan ukuran besar memiliki citra baik dimata publik dan biasanya diawasi oleh pihak yang memiliki kepentingan secara ketat. Perusahaan besar cenderung mendapat tekanan sehingga dalam penyampaian laporan keuangannya dilakukan secara tepat waktu.

Berdasarkan latar belakang yang telah disampaikan, maka peneliti mengusulkan penelitian dengan judul, “ Pengaruh Profitabilitas dan Kompleksitas Operasi Perusahaan Pada Audit delay dengan Ukuran Perusahaan sebagai Variabel Pemoderasi (Studi Empiris Pada Perusahaan Pertambangan yang Terdaftar di Bursa Efek Indonesia Tahun 2013 - 2017). Rumusan masalah dalam penelitian ini adalah: 1) Bagaimana pengaruh profitabilitas pada audit delay?; 2) Bagaimana pengaruh kompleksitas operasi pada audit delay?; 3) Bagaimana kemampuan ukuran perusahaan memoderasi pengaruh profitabilitas pada audit delay?; 4) Bagaimana kemampuan ukuran perusahaan memoderasi pengaruh kompleksitas operasi pada audit delay? Tujuan penelitian ini adalah: 1) menguji secara empiris pengaruh profitabilitas pada audit delay; 2) menguji secara empiris pengaruh kompleksitas operasi pada audit delay; 3) menguji secara empiris kemampuan ukuran perusahaan memoderasi pengaruh profitabilitas pada audit delay; 4) 
menguji secara empiris kemampuan ukuran perusahaan memoderasi pengaruh kompleksitas operasi pada audit delay.

Teori keagenan (agency theory) menjelaskan bahwa hubungan agensi muncul ketika satu orang atau lebih (principal) memperkerjakan orang lain (agent) untuk memberikan suatu jasa dan kemudian mendelegasikan wewenang pengambilan keputusan kepada agen tersebut.Teori agensi dalam hal ini menjelaskan adanya biaya agensi yang dikeluarkan untuk memonitoring perilaku agen sehingga waktu pelaporan laporan keuangan auditan yang lambat akan dapat diatasi (Jensen dan Meckling, 1976)

Signalling theory adalah informasi mengenai perusahaan merupakan sinyal bagi investor, dalam keputusan berinvestasi. Sinyal dapat berupa informasi bersifat financial maupun non-financial yang menyatakan bahwa perusahaan tersebut lebih baik daripada perusahaan lain. Ross (1977) menyatakan bahwa pihak eksekutif perusahaan memiliki informasi lebih baik mengenai perusahaannya akan terdorong untuk menyampaikan informasi tersebut kepada calon investor agar harga saham perusahaannya meningkat.

Audit delay adalah senjang waktu audit, yaitu waktu yang dibutuhkan oleh auditor untuk menghasilkan laporan audit atas kinerja laporan keuangan suatu perusahaan (Ari dan Sari, 2016). Dyer dan McHugh (1975) membagi keterlambatan atau lag menjadi tiga, yaitu Preliminary Lag, Auditor Signature's Lag, Total Lag,

Profitabilitas adalah indikator keberhasilan perusahaan dalam kinerja untuk menghasilkan laba (Wulan danWiratmaja, 2017). Profitabilitas adalah salah satu 
dari indikator bahwa perusahaan telah berhasil dalam menghasilkan laba, sehingga apabila semakin tinggi profitabilitas maka semakin tinggi kemampuan perusahaan untuk menghasilkan laba bagi perusahaannya.

Kompleksitas operasi perusahaan merupakan salah satu karakteristik perusahaan yang dapat meningkatkan suatu tantangan pada audit dan akuntansi.Organisasi dengan banyak jenis atau jumlah pekerjaan dan unit menimbulkan masalah manajerial dan organisasi yang lebih rumit karena terjadi ketergantungan yang semakin kompleks

Ukuran perusahaan merupakan besar kecil suatu perusahaan yang dapat diukur dengan berbagai cara antara lain dinyatakan dengan total assets, nilai pasar saham, jumlah penjualan dalam satu tahun periode penjualan, jumlah tenaga kerja, dan total nilai buku tetap perusahaan (Fauzyah, 2016)

Berdasarkan signaling theory, perusahaan dengan profitabilitas yang tinggi akan cenderung mempercepat publikasi laporan keuangan. Hal ini dikarena profitabilitas yang tinggi merupakan good news bagi investor, begitu pun sebaliknya. Penelitian oleh Andi Kartika (2011) menyatakan bahwa perusahaan tidak akan menunda penyampaian informasi yang berisi berita baik. Oleh karena itu, perusahaan akan berusaha segera menyampaikan good news tersebut, sehingga audit delay yang yang terjadi lebih pendek.

Hasil penelitian tersebut juga didukung oleh Wulan dan Wiratmaja (2017) yang menjelaskan bahwa profitabilitas berimplikasi negatif terhadap audit delay. Dalam penelitiannya, dijelaskan bahwa perusahaan yang memiliki tingkat profitabilitas yang tinggi akan berharap auditor dapat melaksanakan audit dengan 
tepat waktu. Hal ini bertujuan untuk menunjukkan bahwa perusahaan memiliki kinerja yang baik kepada investor. Menurut Prabasari dan Lely (2017) dalam penelitiannya menjelaskan bahwa perusahaan yang memiliki profitabilitas tinggi memiliki intensif yang lebih tinggi dalam penyelesaian pekerjaan audit lebih cepat. Berdasarkan penelitiannya, ditemukan bahwa profitabilitas berimplikasi negatif pada ketepatan waktu penyampaian laporan.

\section{$\mathrm{H}_{1}$ : Profitabilitas berpegaruh negatif terhadap audit delay}

Berdasarkan agency theory, semakin kompleks operasi suatu perusahaan maka semakin banyak informasi yang perlu diungkap dan meningkatkan biaya agensi akan membuat lamanya proses audit. Menurut Che-Ahmad dan Abidin (2009) perusahaan yang memiliki anak perusahaan berarti perusahaan memiliki lebih banyak unit operasi yang harus diperiksa, sehingga auditor dalam proses auditnya membutuhkan waktu yang lebih lama. Menurut Yoga dan Sari (2017) dalam penelitiannya menemukan bahwa kompleksitas operasi berpengaruh positif padaaudit delay sejalan dengan hasil penelitian dari Dewi \& Suputra (2017).

$\mathrm{H}_{2}$ : Kompleksitas operasi berpengaruh positif terhadap audit delay

Perusahaan dengan profitabilitas yang tinggi, cenderung mendorong agar auditor melaksanakan proses proses audit secara efisien, sehingga laporan keuangan dapat diumumkan tepat waktu(Wulan danWiratmaja, 2017). Perusahaan dengan ukuran yang besar akan memiliki pengendalian internal yang lebih ketat dibandingkan dengan perusahaan dengan ukuran yang lebih kecil. Pengendalian internal dan sistem yang baik akan meminimalisir kesalahan penyusunan laporan keuangan (Pourali et al, 2013), sehingga pihak auditor dapat dengan segera 
menyelesaikan proses audit secara tepat waktu yang merupakan goodnews bagi pihak pemakai laporan keuangan sesuai dengan teori sinyal. Menurut Mega dan Budhiarta (2018) dalam penelitiannya menemukan bahwa ukuran perusahaan memperkuat pengaruh profitabilitas pada audit delay. Hasil penelitian senada dari Devi dan Juliarsa (2016) menyatakan bahwa ukuran perusahaan memperkuat pengaruh profitabilitas pada audit delay.

$\mathrm{H}_{3}$ : Ukuran perusahaan memperkuat pengaruh profitabilitas pada audit delay

Kompleksitas operasi perusahaan dapat menjadi faktor yang menyebabkan lamanya audit delay yang disebabkan oleh dibutuhakannya lebih banyak waktu oleh auditor untuk untuk mengaudit cabang dari perusahaan sebelum melakukan audit terhadap induk perusahaan(Ashton, 1987). Berkaitan dengan ukuran perusahaan, perusahaan dengan ukuran yang besar cenderung memiliki diversifikasi usaha yang akan meningkatkan kompleksitas operasi perusahaan. Sejalan dengan teori agensi, semakin kompleks suatu perusahaan maka semakin banyak informasi yang diungkap dan meningkatkan biaya agensi. Hal ini menyebabkan audit delay yang terjadi akan semakin panjang.

Kompleksitas yang lebih tinggi mencerminkan bahwa perusahaan memiliki unit operasi beserta transaksi dan catatan yang harus diperiksa, sehinggaauditor memerlukan waktu lebih lama untuk melakukan pekerjaan auditnya.

$\mathrm{H}_{4}$ : Ukuran perusahaan memperkuat pengaruh kompleksitas pada audit delay 


\section{METODE PENELITIAN}

Penelitian ini dilaksanakan di perusahaan pertambangan yang terdaftar di Bursa Efek Indonesia (BEI) Tahun 2013-2017. Variabel independen yang digunakan dalam penelitian ini adalah profitabilitas dan kompleksitas operasi. Variabel dependen yaitu audit delay, dan variabel pemoderasi adalah ukuran perusahaan. Desain penelitian yang digunakan adalah sebagai berikut.

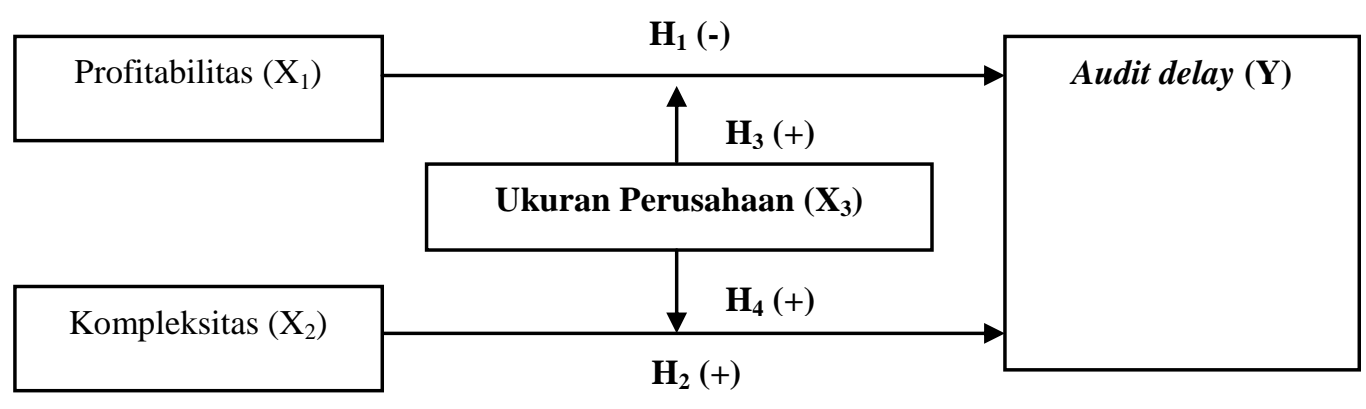

\section{Gambar 1. Desain Penelitian}

Sumber: Data diolah, 2019

Pengukuran audit delay dalam penelitian inidiukur dengan menghitung selisih hari antara tanggal tutup buku laporan keuangan tahunan dengan tanggal laporan auditor independen ditandatangani.

Dalam penelitian ini tingkat profitabilitas diproksi menggunakan Return on Asset (ROA), yang diukur dengan cara sebagai berikut:

$$
\text { Return on Asset } \frac{\text { Laba setelah pajak }}{\text { Total Asset }} \times 100 \% \text {. }
$$

Kompleksitas operasi dalam penelitian ini diproksikan dengan anak perusahaann. Variabel ini dapat diukur dengan dengan menghitung jumlah anak perusahaan yang dimiliki.

Ukuran perusahaan dalam penelitian ini diukur dengan menggunakan nilai logaritma natural total asset. Logaritma natural yang digunakan dalam 
pengukuran ini untuk mengurangi fluktuasi data yang berlebih untuk menghaluskan besarnya angka.

Ukuran Perusahaan $=\mathrm{Ln}($ Total Asset $)$

Populasi penelitian ini adalah seluruh perusahaan pertambangan yang terdaftar di Bursa Efek Indonesia (BEI)periode 2013-2017. Metode non probability sampling digunakan dalam penentuan sampel, dengan teknik purposive sampling dengan kriteria menerbitkan laporan keuangan tahunan auditan tahun 2013-2017, laporan keuangan dinyatakan dalam rupiah, memuat informasi mengenai audit delay, profitabilitas, kompleksitas operasi, dan ukuran perusahaan.

Penelitian ini menggunakan uji Regresi Linear Berganda dan uji Moderated Regression Analysis (MRA) sebagai teknik analisis data. Analisis regresi linier berganda yang merupakan sebuah metode yang digunakan untuk mengukur kekuatan hubungan antara variabel bebas dan variabel terikat.

$\mathrm{Y}=\alpha+\beta_{1} \mathrm{X}_{1}+\beta_{2} \mathrm{X}_{2}+\mathrm{e}$

Keterangan :

$\mathrm{Y} \quad=$ Audit Delay

$\alpha \quad=$ Konstanta

$\beta_{1}, \beta_{2}$, = Koefisien regresi variabel bebas

$\mathrm{X}_{1}=$ Profitabilitas

$\mathrm{X}_{2} \quad=$ Kompleksitas Operasi

e $\quad=$ Variabel pengganggu / standard error

Uji MRA merupakan aplikasi khusus regresi linier berganda, dimana dalam persamaan regresinya mengandung unsur interaksi (perkalian dua atau lebih variabel independen).

$\mathrm{Y}=\alpha+\beta_{1} \mathrm{X}_{1}+\beta_{2} \mathrm{X}_{2}+\beta_{3} \mathrm{X}_{3}+\beta_{4} \mathrm{X} 1 \mathrm{X} 3+\beta_{5} \mathrm{X}_{2} \mathrm{X}_{3}+\mathrm{e}$ 
$\mathrm{Y}=$ Audit delay

$\alpha=$ Konstanta

$\beta=$ Koefisien Regresi

$\mathrm{X}_{1}=$ Profitabilitas

$\mathrm{X}_{2}=$ Kompleksitas Operasi

$\mathrm{X}_{3}=$ Ukuran Perusahaan

$\mathrm{X}_{1} \mathrm{X}_{3}=$ Interaksi antara profitabilitas dengan ukuran perusahaan

$\mathrm{X}_{2} \mathrm{X}_{3}=$ Interaksi antara kompleksitas dengan ukuran perusahaan

\section{HASIL DAN PEMBAHASAN}

Penelitian ini menggunakan metode non probability sampling dengan teknik purposive sampling. Setelah menerapkan purposive sampling, dengan kriteria menerbitkan laporan keuangan yang telah diaudit tahun 2013-2017, bemata uang rupiah, dan menyajikan informasi mengenai audit delay, profitabilitas, kompleksitas operasi dan ukuran perusahaan. Maka dari 235 populasi yang memenuhi kriteria berjumlah 50 sampel. Seleksi sampel disajikan pada Tabel 1.

Tabel 1.

Seleksi Sampel Penelitian

\begin{tabular}{ll}
\hline Keterangan & Jumlah \\
& Perusahaan \\
\hline Populasi perusahaan pertambangan yang terdaftar di Bursa Efek Indonesia tahun & 235 \\
2013-2017 & \\
1. $\quad \begin{array}{l}\text { Perusahaan pertambangan yang belum menerbitkan laporan keuangan } \\
\text { tahunan yang telah diaudit 2013-2017 }\end{array}$ & \\
2. $\quad \begin{array}{l}\text { Perusahaan pertambangan yang dalam laporan keuangannya dinyatakan } \\
\text { dalam mata uang asing }\end{array}$ & $(110)$ \\
3. $\begin{array}{l}\text { Perusahaan yang dalam laporannya tidak lengkap menyajikan informasi } \\
\text { mengenai variabel audit delay, profitabilitas, kompleksitas operasi, dan }\end{array}$ & \\
$\quad \begin{array}{l}\text { ukuran perusahaan } \\
\text { Jumlah sampel }\end{array}$ & 50 \\
Jumlah perusahaan & 10 \\
\hline
\end{tabular}

Sumber: Data diolah, 2019

Sebelum pengolahan data didahului dengan melakukan pendeteksian adanya data outlier. Data outlier yang dapat dilihat dari nilai dari Z-Score lebih dari 2,5 sebanyak 5 pengamatan, sehingga total pengamatan menjadi 45 pengamatan. 
Berdasarkan hasil pengolahan SPSS yang meliputi variabel audit delay (Y), profitabilitas $\left(\mathrm{X}_{1}\right)$,kompleksitas operasi $\left(\mathrm{X}_{2}\right)$, dan ukuran perusahaan $\left(\mathrm{X}_{3}\right)$ menunjukkan hasil statistik deskriptif yang dapat dilihat pada Tabel 2.

Tabel 2.

Hasil Uji Statistik Deskriptif

\begin{tabular}{lllll}
\hline & Nilai & Nilai & Mean & Standar \\
& Minimum & Maksimum & & Deviasi \\
\hline Audit delay $(\mathrm{Y})$ & 17 & 119 & 70,02 & 20,97 \\
Profitabilitas $\left(\mathrm{X}_{1}\right)$ & $-0,27$ & 0,22 & $-0,18$ & 0,94 \\
K. Operasi $\left(\mathrm{X}_{2}\right)$ & 2,0 & 20 & 7,00 & 4,39 \\
Ukuran Perusahaan $\left(\mathrm{X}_{3}\right)$ & 26,16 & 31,03 & 28,63 & 1,31 \\
\hline
\end{tabular}

Sumber :Data diolah, 2019

Berdasarkan Tabel 2 hasil uji statistik deskriptif menunjukkan nilai maksimum untuk variabel audit delay, profitabilitas, kompleksitas operasi, dan ukuran perusahaan masing - masing sebesar $119 ; 0,22 ; 20 ; 31,03$ dan nilai minimumnya sebesar $17 ;-0,27 ; 2,0 ; 26,16$. Dilihat dari nilai maksimum dan minimum variabel audit delay, profitabilitas, kompleksitas operasi, dan ukuran perusahaan maka didapat nilai mean masing - masing sebesar 70,02; -0,18; 7,00; 28,63. Nilai standar deviasi berarti terjadi penyimpangan terhadap nilai rata - rata (mean) masing - masing variabel dimulai dari audit delay, profitabilitas, kompleksitas operasi, dan ukuran perusahaan sebesar 20,97; 0,94; 4,39; 1,31.

Sebelum dilakukan analisis regresi, dilakukan uji asumsi klasik yang meliputi uji normalitas, uji multikolonieritas, uji autokorelasi, dan uji heteroskedastisitas.

Tabel 3.

Uji Normalitas

\begin{tabular}{lll}
\hline & Unstandardized Residual & Unstandardized Residual \\
& Persamaan RegresiBerganda & Persamaan Regresi Moderasi \\
\hline $\mathrm{N}$ & 45 & 45 \\
Asymp. Sig. (2-tailed) & 0,655 & 0,164 \\
\hline Sumber: Data diolah, 2019 & &
\end{tabular}


Berdasarkan Tabel 3 menunjukkan nilai asymp. Sig pada persamaan regresi berganda bernilai 0,655 . Persamaan regresi moderasi memiliki nilai asymp. Sig bernilai 0,164. Hasil tersebut menunjukkan bahwa persamaan regresi berganda dan regresi moderasi telah berdistribusi normal karena memiliki Asymp. Sig. lebih besar dari 0,05.

\section{Tabel 4.}

Hasil Uji Multikolonieritas

\begin{tabular}{lll}
\hline & \multicolumn{2}{l}{ Collinearity Statistics } \\
& Tolerance & VIF \\
\hline Profitabilitas & 0,751 & 1,332 \\
K. Operasi & 0,312 & 3,202 \\
Ukuran Perusahaan & 0,265 & 3,773 \\
\hline Dependent Variable: Audit delay & & \\
\hline Sumber: Data diolah, 2019 & &
\end{tabular}

Berdasarkan Tabel 4 menunjukkan bahwa nilai tolerance masing-masing variabel lebih besar dari $10 \%$ atau 0,1 . Nilai VIF masing-masing variabel lebih kecil dari 10. Hal ini menjelaskan bahwa tidak terdapat gejala multikolinieritas, karena nilai tolerance lebih besar daro 0,10 dan nilai VIF lebih kecil dari 10.

Tabel 5.

Hasil Uji Durbin Watson

\begin{tabular}{lll}
\hline No. & Model & DW \\
\hline 1 & Persamaan Regresi Berganda & 2,063 \\
2 & Persamaan Regresi Moderasi & 2,119 \\
\hline Sumber: & Data diolah, 2019
\end{tabular}

Tabel 5 menunjukkan bahwa dalam model persamaan regresi berganda memiliki nilai Durbin-Watson sebesar 2,063. Untuk tingkat signifikansi 5\% jumlah sampel (n) sebanyak 45 dan jumlah variabel bebas (k) sebanyak 3, nilai $\mathrm{dl}=1,3832$ dan $d u=1,6662$. Berdasarkan hasil uji Durbin-Watson bernilai 2,063 > 1,6662 dan $<4-2,063$. Model regresi moderasi memiliki nilai Durbin-Watson sebesar 2,119, hasil uji 2,119>1,6662 dan <4-2,119. Maka disimpulkan bahwa 
model regresi berganda dan model regresi moderasi yang digunakan tidak terdapat gejala autokorelasi.

Tabel 6.

Hasil Uji Heteroskedastisitas

\begin{tabular}{llll}
\hline No. & Model & Variabel & Signifikansi \\
\hline 1 & Persamaan Regresi Berganda & Profitabilitas & 0,088 \\
& & K. Operasi & 0,983 \\
& \multirow{3}{*}{ Persamaan Regresi Moderasi } & Ukuran Perusahaan & 0,649 \\
& & Profitabilitas & 0,358 \\
& K. Operasi & 0,836 \\
& & Ukuran Perusahaan & 0,117 \\
& X1_Z & 0,323 \\
& X2_Z & 0,855 \\
\hline
\end{tabular}

Sumber: Data diolah, 2019

Hasil Tabel 6 menunjukkan bahwa masing-masing variabel dalam model persamaan regresi berganda dan persamaan regresi moderasi memiliki nilai siginifikansi lebih besar dari 0,05 yang berarti bahwa tidak terdapat heteroskedastisitas pada penelitian ini.

Tabel 7.

Hasil Uji Regresi Linear Berganda

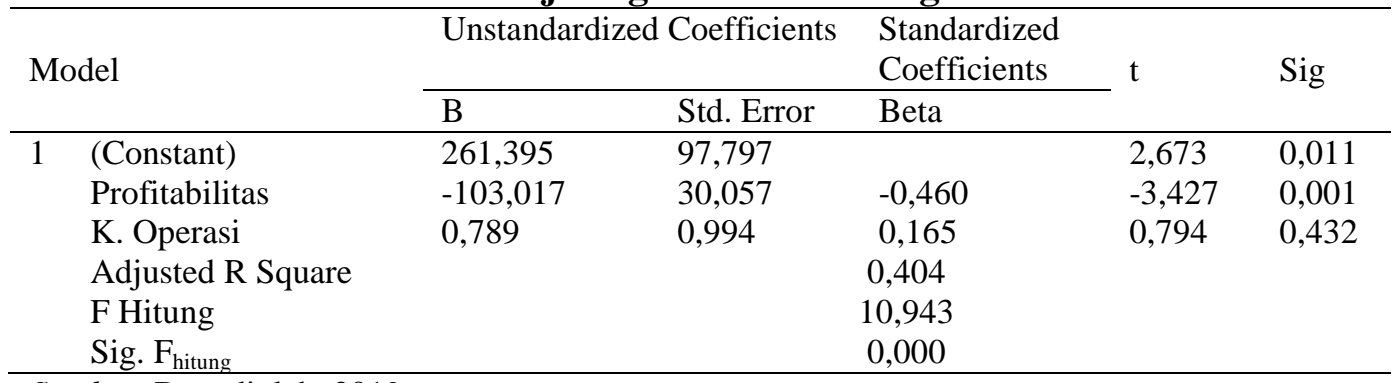

Sumber: Data diolah, 2019

Berdasarkan pada hasil koefisien regresi pada tabel 7 diatas, maka dapat dibuat model persamaan regresi linear berganda sebagai berikut.

$\mathrm{Y}=261,395+-103,017 \mathrm{X}_{1}+0,789 \mathrm{X}_{2}+\mathrm{e}$

Nilai $\beta_{1}=-103,017$; menunjukkan bahwa profitabilitas berpengaruh negatif pada audit delay. Hal ini berarti apabila variabel profitabilitas meningkat maka terjadi 
penurunan pada audit delay dengan asumsi variabel bebas lainnya dianggap konstan.

Nilai $\beta_{2}=0,789$; menunjukkan bahwa kompleksitas operasi berpengaruh positif pada audit delay. Hal ini berarti apabila variabel kompleksitas operasi meningkat maka terjadipeningkatan padaaudit delay dengan asumsi variabel bebas lainnya dianggap konstan.

Besarnya nilai koefisien determinasi ditunjukkan dengan nilai $\mathrm{R}$ square $\left(\mathrm{R}^{2}\right)$ adalah 0,404. Hasil ini berarti 40,4\% variasi dalam audit delay dapat dijelaskan oleh variabel profitabilitas dan kompleksitas operasi, sementara itu $59,6 \%$ variasi pada audit delay dipengaruhi oleh variabel-variabel lain yang tidak diteliti pada model penelitian ini.

Nilai Sig. untuk pengujian model (Ftest) adalah sebesar 0,000 nilai ini lebih kecil dari $\alpha=0,05$ sehingga model dikategorikan layak untuk digunakan dalam tahapan uji berikutnya.

Tabel 8.

Hasil Uji MRA

\begin{tabular}{|c|c|c|c|c|c|c|}
\hline & & \multicolumn{2}{|c|}{ Unstandardized Coefficients } & \multirow{3}{*}{$\begin{array}{l}\text { Standardized } \\
\text { Coefficients } \\
\text { Beta }\end{array}$} & \multirow{3}{*}{$\mathrm{t}$} & \multirow{3}{*}{ Sig } \\
\hline & & & & & & \\
\hline & & B & Std. Error & & & \\
\hline \multirow[t]{9}{*}{1} & (Constant) & 354,524 & 122,504 & & 2,894 & 0,006 \\
\hline & Profitabilitas & $-1494,693$ & 628,374 & $-6,678$ & $-2,379$ & 0,022 \\
\hline & K. Operasi & $-13,929$ & 16,823 & $-2,919$ & $-0,828$ & 0,413 \\
\hline & Ukuran Perusahaan & $-10,043$ & 4,353 & $-0,627$ & $-2,307$ & 0,026 \\
\hline & $\mathrm{X}_{1 \_\mathrm{Z}}$ & 48,780 & 21,965 & 6,261 & 2,221 & 0,032 \\
\hline & $\mathrm{X}_{2 \_} \mathrm{Z}$ & 0,486 & 0,555 & 3,197 & 0,875 & 0,387 \\
\hline & Adjusted R Square & 0,456 & & & & \\
\hline & F Hitung & 8,356 & & & & \\
\hline & Sig $F_{\text {hitung }}$ & 0,000 & & & & \\
\hline
\end{tabular}

Berdasarkan Tabel 8 diatas, maka dapat diintepretasikan bahwa, interaksi antara variabel profitabilitas dengan ukuran perusahaanmenunjukkan nilai 
koefisien 48,780 dengan nilai signifikansi $(0,032<0,05)$. Hal tersebut menunjukkan bahwa variabel ukuran perusahaanmemperkuat pengaruh antara profitabilitas padaaudit delay.Interaksi antara variabel kompleksitas operasi pada ukuran perusahaan menunjukkan nilai koefisien 0,486 dengan nilai signifikansi $(0,387>0,05)$. Hal tersebut menunjukkan bahwa variabel ukuran perusahaan tidak mampu memoderasi pengaruh kompleksitas operasi pada audit delay.

Nilai adjusted $\mathrm{R}^{2}$ sebesar 0,456 pada regresi moderasi memiliki arti bahwa 45,6\% variasi pada audit delay dapat dijelaskan oleh variabel profitanilitas dan kompleksitas operasi, dan interaksi profitabilitas dan ukuran perusahaan serta interaksi kompleksitas operasi dan ukuran perusahaan. Sementara itu, 54,4\% variasi pada audit delay dipengaruhi oleh variabel-variabel yang tidak diteliti pada model penelitian ini.

Nilai Sig. untuk pengujian model (Ftest) adalah sebesar 0,000 nilai ini lebih kecil dari $\alpha=0,05$ sehingga model dikategorikan layak untuk digunakan dalam tahapan uji berikutnya.

Pengujian hipotesis 1, berdasarkan uji hipotesis (t) menunjukkan hasil koefisien regresi $-103,017$ dengan signifikansi $0,001<$ alpha $=0,05$, berarti $\mathrm{H}_{1}$ diterima. Hal ini menunjukkan bahwa profitabilitas berpengaruh negatif pada audit delay. Hal ini berarti bahwa semakin tinggi profitabilitas suatu perusahaan, maka semakin singkat audit delay yang terjadi. Hasil peneltian ini mendukung penelitian sebelumnya yang dilakukan oleh Wulan dan Wiratmaja (2017), Prabasari dan Lely (2017) yang dalam penelitiannya menyatakan bahwa perusahaan yang memiliki profitabilitas lebih tinggi akan mengalami audit delay 
yang lebih pendek. Audit delay yang relatif pendek pada perusahaan dengan profitabilitas tinggi konsisten dengan teori sinyal karena profitabilitas tinggi oleh manajemen dianggap sebagai good news, hal ini mendorong manajemen untuk segera mempublikasin informasi tersebut. Perusahaan dengan profitabilitas yang tinggi merupakan sinyal bahwa perusahaan dalam kinerja yang baik, untuk itu manajemen akan berupaya agar auditor menyelesaikan laporan audit secara tepat waktu, dengan menyediakan data dan informasi yang dibutuhkan auditor serta mendukung kelancaran pelaksanaan pemeriksaan. Sejalan dengan teori agency, dimana auditor sebagai perwakilan dari prinsipal menganggap bahwa profitabilitas yang tinggi merupakan good news, yang berarti resiko audit akan ditetapkan relatif lebih rendah. Oleh karena itu, auditor untuk menetapkan resiko audit baik resiko bawaan, resiko pengendalian, dan resiko deteksi menjadi relatif lebih rendah, sehingga auditor akan menyederhanakan penerapan prosedur audit, seperti pengambilan sampel yang lebih sedikit sehingga audit delay menjadi lebih pendek. Auditor dalam menghadapi perusahaan dengan profitabilitas rendah cenderung lebih berhati-hati dalam proses audit dengan menerapkan prosedur audit yang lebih ketat dan menetapkan resiko audit lebih tinggi. Hal ini berarti auditor yang menghadapi perusahaan dengan profitabilitas yang tinggi dapat mempersempit lingkup audit yang digunakan dan menetapkan resiko audit relatif lebih rendah untuk mengurangi terjadinya audit delay yang panjang.

Pengujian hipotesis 2, berdasarkan uji hipotesis (t) menunjukkan hasil koefisien regresi 0,789 dengan signifikansi $0,432>$ alpha $=0,05$, berarti $\mathrm{H}_{2}$ ditolak. Hal ini menunjukkan bahwa kompleksitas operasi tidak berpengaruh pada 
audit delay, yang berarti bahwa tingkat kompleksitas operasi suatu perusahaan tidak berpengaruh pada panjangnya audit delay yang dialami oleh perusahaan. Hasil penelitian ini sejalan dengan penelitian sebelumnya yang dilakukan oleh Dian dan Yeni (2014)yang menemukan bahwa kompleksitas operasi tidak berpengaruh pada audit delay. Hal ini mungkin disebabkan karena perusahaan dengan kompleksitas yang tinggi telah menyadari bahwa auditor akan menetapkan resiko audit relatif lebih tinggi, sehingga perusahaan telah mempersiapkan buktibukti yang dibutuhkan oleh auditor. Hal lain yang dapat menyebabkan kompleksitas operasi tidak berpengaruh pada audit delay, yaitu auditor yang melakukan proses audit pada perusahaan pertambangan dalam penelitian ini telah membuat perancanaan audit dengan baik, memilih auditor yang kompeten, dan memenuhi kecukupan sumber daya manusia dalam melakukan proses audit. Disaat perencanaan audit, pemilihan staff auditor telah dilakukan dengan baik, maka kompleksitas operasi tidak berpengaruh pada lamanya waktu audit yang dibutuhkan. Auditor dalam melakukan proses audit pada perusahaan dengan kompleksitas operasi yang tinggi tidak perlu menetapkan resiko audit yang lebih tinggi sepanjang telah membuat perencanaan audit dengan baik, memilih staff yang kompeten dengan jumlah yang memadai. Kompleksitas operasi pada industri pertambangan mungkin saja memiliki karakteristik berbeda dengan bidang industri lain yang diteliti Dian dan Yeni(2014). Perbedaan hasil penelitian ini kemungkinan disebabkan oleh perbedaan sampel penelitian, sampel yang dipilih yaitu perusahaan yang mengalami audit delay sehingga sampel penelitiannya relatif homogen dibandingkan sampel pada penelitian ini. 
Pengujian hipotesis 3, berdasarkan uji hipotesis (t) menunjukkan hasil koefisien regresi 48,780 dengan signifikansi $0,032<$ alpha $=0,05$, berarti $\mathrm{H}_{3}$ diterima. Hal ini menunjukkan ukuran perusahaan memperkuat pengaruh negatif profitabilitas terhadap audit delay, yang berarti perusahaan dengan profitabilitas tinggi dengan ukuran yang besar, maka semakin singkat terjadinya audit delay.

Hasil penelitian sejalan dan mendukung penelitian sebelumnya yang dilakukan oleh Mega dan Budhiarta (2018) yang dalam penelitiannya menyatakan bahwa pengendalian internal pada perusahaan besar lebih kuat dibanding perushaan kecil, kontrol internal yang efektif mampu meminimalisir kemungkinan adanya kesalahan dalam penyajian laporan keungan.Auditor dalam proses auditnya dapat memperhatikan pengendalian internal dari perusahaan yang akan diaudit. Jika perusahaan memiliki pengendalian internal yang baik maka auditor dapat menetapkan resiko audit yang relatif lebih rendah sehingga ruang sampel yang digunakan semakin kecil sehingga memperpendek audit delay. Perusahaan dengan kontrol yang efektif dapat menyediakan segala dokumen dan berkas pendukung lainnya yang diperlukan auditor dalam pelaksanaan proses audit, yangmenyebabkan kemungkinan perusahaan mengalami audit delay semakin kecil. Perusahaan dengan ukuran yang besar juga memiliki kemampuan keuangan untuk memilih Kantor Akuntan Publik (KAP) dengan reputasi tinggi, dimana KAP dengan reputasi yang tinggi memiliki sumber daya dan kompetensi staff yang memadai untuk menjamin audit dapat diselesaikan secara tepat waktu.

Pengujian hipotesis 4, berdasarkan uji hipotesis (t) menunjukkan hasil koefisien regresi 0,486 dengan signifikansi $0,387>$ alpha $=0,05$, berarti $\mathrm{H}_{4}$ 
ditolak. Hal ini menunjukkan ukuran perusahaan tidak mampu memoderasi pengaruh kompleksitas operasi terhadap audit delay, yang berarti bahwa ukuran perusahaan tidak memperkuat ataupun memperlemah pengaruh kompleksitas operasi pada audit delay.Jenis moderasi dalam model ini diklasifikasikan sebagai potensial/homologiser moderasi. Hal ini berarti variabel ukuran perusahaan berpotensi menjadi variabel moderasi.Hal ini dapat disebabkan perusahaan besar telah memiliki sistem informasi dan internal control yang memadai, dan tenaga staff akuntan internal dengan kecakapan yang tinggi,sehingga dalam proses audit dapat bekerjasama dengan auditor dalam penyediaan bukti-bukti pendukung yang diperlukan yang akhirnya memperpendek waktu yang diperlukan dalam penyelesaian audit.

Penelitian ini mengkonfirmasi teori sinyaldan teori agency. Teori sinyal membantu dalam memahami profitabilitas yang tinggi bagi perusahaan merupakan berita baik yang harus segera disampaikan kepada pihak pengguna laporan keuangan khususnya investor. Hal ini dikarenakan profitabilitas yang tinggi merupakan good news bagi investor, begitu pun sebaliknya. Teori agensi dikonfirmasi melalui auditor yang merupakan perwakilan dari prinsipal menganggap bahwa profitabilitas yang tinggi merupakan good news, yang berarti resiko audit yang akan ditetapkan oleh auditor relatiflebih rendah.

Penelitian ini diharapkan dapat memberikan manfaat positif bagi semua pihak berkepentingan baik auditor independen, perusahaan, maupun investor.Pemahaman yang lebih baik mengenai faktor-faktor yang mempengaruhi audit delay diperlukan oleh auditor independen sehingga penyelesaian laporan 
auditor independen dapat diselesaikan dengan efektif dan efisien secara tepat waktu. Bagi perusahan dengan profitabilitas yang rendah, agar dapat mempersiapkan segala keperluan untuk medukung proses audit yang tepat waktu. Bagi investor, dapat menilai kinerja perusahaan melalui audit delay yang terjadi.

\section{SIMPULAN}

Profitabilitas berpengaruh negatif terhadap audit delay yang berarti semakin tinggi profitabilitas suatu perusahaan, maka semakin pendek audit delay.

Kompleksitas operasi tidak berpengaruh terhadap audit delay. Hal ini berarti bahwa kompleksitas operasi suatu perusahaan tidak mempengaruhi panjang atau pendeknya audit delay.

Ukuran perusahaan mampu memoderasi pengaruh profitabilitas terhadap audit delay. Hal ini berarti bahwa besar kecilnya ukuran suatu perusahaan dan sekaligus tinggi rendahnya tingkat profitabilitas suatu perusahaan mempengaruhi jangka waktu penyelesaian audit.

Ukuran perusahaan tidak mampu memoderasi pengaruh kompleksitas operasi terhadap audit delay. Hal ini berarti bahwa besar kecilnya ukuran suatu perusahaan dan sekaligus tinggi rendahnya kompleksitas operasi suatu perusahaan tidak mempengaruhi mempengaruhi jangka waktu penyelesaian audit.

Penelitian ini memiliki keterbatasan dalam penggunaan pengukuran audit delay dengan menghitung selisih jumlah hari dari tanggal tutup buku sampai dengan tanggal pada laporan auditor independen. Pengukuran audit delay 
seharusnya menghitung selisih hari keterlambatan penerbitan laporan auditor independen dengan tanggal yang disepakati pada perikatan audit.

Berdasarkan hasil penelitian dan keterbataasan penelitian ini, maka saran yang dikemukakan yaitu, bagi perusahaan yang mengalami profitabilitas yang relaif rendah, disarankan agar mempersiapan laporan keuangan secara lengkap dan tepat waktu serta bersikap kooperatif dengan auditor sehingga mengurangi audit delay serta bagi peneliti selanjutnya, diharapakan dapat menggunakan alat pengukuran lain untuk audit delay, yaitu menghitung jumlah hari keterlambatan penyelesaian laporan audit dengan yang disepakati dalam perikatan audit antara klien dengan auditor.

\section{REFERENSI}

Amani, Fauziyah Althaf. 2016. Pengaruh Ukuran Perusahaan, Profitabilitas, Opini Audit, Dan Umur Perusahaan Terhadap Audit Delay (Studi Empiris Pada Perusahaan Property Dan Real Estate Yang Terdaftar Di Bursa Efek Indonesia Pada Tahun 2012-2014). Jurnal Nominal. Vol. 1, hlm: 135-150.

Angruningrum, Silviadan Made Gede Wirakusuma. 2013. Pengaruh Profitabilitas, Leverage, Kompleksitas Operasi, Reputasi KAP dan Komite Audit Pada Audit Delay. E-Jurnal Akuntansi Universitas Udayana. Vol. 5, No. 2, hlm: 251-270.

Ashton, R. H., Willingham, J. J., dan Elliott, R. K. 1987. An Empirical Analysis of Audit Delay. Journal of Accounting Research. Vol.25, No. 2,hlm: 275292.

Carslaw, C. A. P. N., dan Kaplan, S. E. 1991. An Examination of Audit Delay: Further Evidence from New Zealand. Accounting and Business Research. 22(85),hlm: 21-32.

Che-Ahmad, A danS. Abidin. 2009. Audit Delay of Listed Companies: A Case of Malaysia. International Business Research. Vol. 1, No. 4, hlm: 32-39. 
Darmawan, I Putu Yoga dan Ni Luh SAri Widhiyani. 2017. Pengaruh Ukuran Perusahaan, Kompleksitas Operasi dan Komite Audit Pada Audit Delay. EJurnal Akuntansi Universitas Udayana. Vol. 21, No. 1, hlm: 254-282.

Dewi, G.A Nyoman Purnama dan I Gde Dharma Suputra. 2017. Pengaruh Kompleksitas Operasi Perusahaan, Kontinjensi, dan Pergantian Auditor pada Audit Report Lag dengan Spesialisasi Auditor Sebagi Pemoderasi. E-Jurnal Akuntansi Universitas Udayana. Vol. 21, No. 2, hlm: 912-941.

Dyer, J.D. dan McHugh. 1975. The Timeliness of the Australian Annual Report. Journal of Accounting Research. h: 204-219.

Ilaboya, O. J. dan Christian, I. 2014. Corporate governance and audit report lag in Nigeria. International Journal of Humanities and Social Science. Vol. 4, No. 13, hlm: 172-180.

Jensen, M. C dan Meckling. 1976. Theory of the Firm: Managerial Behavior, Agency Costs and Ownership Structure Theory of the Firm: Managerial Behavior, Agency Costs and Ownership Structure. Journal of Financial Economics. Vol.3, No. 4, hlm: 305-360.

Kartika, Andi. 2011. Faktor-faktor yang mempengaruhi audit delay pada perusahaan manufaktur yang terdaftar di BEI. Dinamika Keuangan Dan Perbankan. Vol. 3, No. 2

Lapinayanti, Ni Made Mega dan I Ketut Budiartha. 2018. Pengaruh Profitabilitas dan Leverage Pada Audit Delay dengan Ukuran Perusahan Sebagai Pemoderasi. E-Jurnal Akuntansi Universitas Udayana. Vol. 23,No. 2, hlm: 1066-1092.

Miradhi, Made Devi dan Gede Juliarsa. 2016. Ukuran Perusahaan Sebagai Pemoderasi Pengaruh Profitabilitas dan Opini Auditor pada Audit Delay. EJurnal Akuntansi Universitas Udayana. Vol. 16, No. 1, hlm: 288-415.

Murti, Ni Made Dwi Ari dan Ni Luh Sari Widhiyani. 2016. Pengaruh Ukuran Perusahaan dan Profitabilitas Pada Audit Delay Dengan Reputasi KAP Sebagai Variabel Pemoderasi. E-Jurnal Akuntansi Universitas Udayana. Vol.16, No. 1, hlm: 275-305.

Owusu-Ansah, S. 2000. Timeliness of corporate financial reporting in emerging capital markets: Empirical evidence from the Zimbabwe Stock Exchange. Accounting and Business Research. hlm: 241-254.

Pourali, M. R., Jozi, M., Rostami, K. H., Taherpour, G. R., dan Niazi, F. 2013. Investigation of effective factors in audit delay: Evidence from tehran stock exchange (TSE). Research Journal of Applied Sciences, Engineering and 
Technology. Vol. 5, No. 2, hlm: 405-410.

Prabasari, IGA Ayu Ratih dan Ni Ketut Lely Aryani Merkusiwati. 2017. Pengaruh Profitabilitas, Ukuran Perusahaan, dan Komite Audit Pada Audit Delay yang Dimoderasi oleh Reputasi KAP. E-Jurnal Akuntansi Universitas Udayana. Vol. 20, No. 2, hlm: 1704-1733.

Puspitasari, Ketut Dian dan Made Yeni Latrini. 2014. Pengaruh Ukuran Perusahaan, Anak Perusahaan, Leverage dan Ukuran Kap Terhadap Audit Delay. E-Jurnal Akuntansi Universitas Udayana. Vol. 8, No. 2, hlm: 283299.

Ross, S. A. 1977. The Determination of Financial Structure: The IncentiveSignalling Approach. The Bell Journal of Economics.pp: 23-40. 